\title{
Non-lactational Infectious Mastitis in the Americas: A Systematic Review
}

\author{
Victor Costa Morais Oliveira ${ }^{1,2,3}$, Nadia Cubas-Vega ${ }^{1,3}$, Paola López Del-Tejo ${ }^{1,3}$, \\ Djane C. Baía-da-Silva ${ }^{1,3}$, Michel Araújo Tavares ${ }^{4}$, Izabella Picinin Safe ${ }^{1}$, \\ Marcelo Cordeiro-Santos ${ }^{1,3,5}$, Marcus Vinícius Guimarães Lacerda ${ }^{1,3,6}$ and Fernando Val ${ }^{1,3 *}$ \\ ${ }^{1}$ Fundação de Medicina Tropical Dr. Heitor Vieira Dourado, Manaus, Brazil, ${ }^{2}$ Fundação Hospital Adriano Jorge, Manaus, \\ Brazil, ${ }^{3}$ Programa de Pós-graduação em Medicina Tropical, Universidade Do Estado Do Amazonas, Manaus, Brazil, \\ ${ }^{4}$ Faculdade de Medicina, Universidade Federal Do Amazonas, Manaus, Brazil, ${ }^{5}$ Departamento de Ensino e Pesquisa, \\ Universidade Nitton Lins, Manaus, Brazil, ${ }^{6}$ Rede de Pesquisa em Malária, Instituto Leônidas and Maria Deane, \\ Fiocruz-Amazonas, Manaus, Brazil
}

\section{OPEN ACCESS}

Edited by:

Yousef Saleh Khader,

Jordan University of Science and

Technology, Jordan

Reviewed by:

Gobena Ameni,

Addis Ababa University, Ethiopia

Dongdong $\mathrm{Li}$

Sichuan University, China

*Correspondence:

Fernando Val

ffaval@gmail.com

Specialty section:

This article was submitted to Infectious Diseases-Surveillance,

Prevention and Treatment,

a section of the journal

Frontiers in Medicine

Received: 22 March 2021

Accepted: 05 July 2021

Published: 02 August 2021

Citation:

Costa Morais Oliveira V Cubas-Vega N, López Del-Tejo P, Baía-da-Silva DC, Araújo Tavares M, Picinin Safe I, Cordeiro-Santos M,

Lacerda MVG and Val F (2021) Non-lactational Infectious Mastitis in the Americas: A Systematic Review. Front. Med. 8:672513. doi: 10.3389/fmed.2021.672513
Background: Non-lactational infectious mastitis (NLIM) is an inflammatory breast disease with broad clinical presentation. Inadequate treatment can lead to chronic infections that cause breast deformities. NLIM information is limited, especially in the Americas. A systematic review and meta-analysis have been conducted here.

Methods: Literature search was conducted in three databases (Lilacs, PubMed, and Scielo) on NLIM cases in the Americas. Demographic, epidemiological, clinical, radiological, and laboratory data were extracted. The main characteristics and results were also compared according to the country's gross national income.

Results: A total of 47 articles were included, resulting in 93 cases. The etiological agent was described in 86 (92.5\%) patients. Bacteria were the most prevalent etiology $(73 ; 84.8 \%)$. Amongst bacterial diagnoses, more frequent cases were Mycobacterium tuberculosis (28; 38.4\%); Corynebacterium spp. (15; 20.5\%); non-tuberculous mycobacteria (13; 17.8\%). The cases were reported in eight different countries, with the USA being the country with the highest number of cases (35; 37.6\%). Patients from high-income countries group presented a shorter diagnostic time when compared to low, low-middle, and upper-middle-income countries. A greater number of radiographic studies with pathological findings were described in high-income countries.

Conclusion: Non-lactational infectious mastitis is a complex public health problem with diagnostic and treatment challenges. Hence, multi-professional approach-based additional studies are recommended on its epidemiology, diagnosis, treatment, and control.

Keywords: non-lactational mastitis, clinical mastitis, granulomatous mastitis, Mycobacterium tuberculosis, epidemiology

\section{INTRODUCTION}

Mastitis is a non-malignant inflammatory breast disease, which may be accompanied by an infection, and affects any anatomical structure of the mammary gland (1-3). Infectious etiologies are more frequent in lactating women (lactational or puerperal mastitis) $(4,5)$. Nonlactational or non-puerperal infectious mastitis (NLIM) can becaused by different infectious agents $(6,7)$. Staphylococcus is the main genus of bacteria associated with non-lactational infectious 
mastitis $(8,9)$, and up to $30 \%$ may be polymicrobial (associated, for example, with Enterobacteriaceae, Peptostreptococcus, Propionibacterium, and Bacteroides) (10). Mycobacterium tuberculosis, non-tuberculous mycobacteria (NTM), and Corynebacterium spp. are considered rare agents associated with NLIM and may be misdiagnosed as idiopathic granulomatous mastitis (IGM) (11-14).

NLIM presents management challenges, a higher number of relapses and complications, such as fistulas, in addition to more significant morbidity and psychological impact in younger patients $(15,16)$. The incidence and prevalence of NLIM are challenging to estimate since most studies are published on lactational mastitis, and those regarding NLIM have several limitations in their methodology. The highest prevalence of NLIM occurs in women of reproductive age, whether breastfeeding or not (17-19). Males of any age can be affected as well (20-22). Kamal et al. (23) observed NLIM prevalence of $41.6 \%$ in women from outpatient clinics and wards.

The understanding of the causes of NLIM is limited. The literature consists mainly of case reports and small case series, and very few of these refer to cases in the Americas. Consequently, there are limited data on epidemiology, diagnostic approach, and treatment as compared to lactational mastitis, even though it is a significant public health problem, especially in low- and middle-income Latin America and the Caribbean. Therefore, we conducted a systematic review of the published literature regarding NLIM cases reported in this geographical region to comprehend the associated factors. Also, we compared characteristics of patients from low, low-middle and uppermiddle-income countries (Latin America) and high-income countries [United States of America (USA) and Canada] according to the World Bank classification based on the gross national income (GNI) per capita [31].

\section{METHODS}

The Preferred Reporting Items for Systematic Reviews and Meta-Analyses (PRISMA) guidelines were followed (24). Studies reporting NLIM were systematically selected by two independent reviewers and identified through multiple electronic databases (Medline/PubMed, Lilacs, and Scielo), using the keywords presented in Table 1 as a search strategy. Any disagreements were resolved by consensus. We also assessed the list of references from the included studies to identify other ones that were not initially detected. Figure 1 presents the study selection flow diagram. The last search was performed in October, 2020. No year or language restrictions were applied. Only case reports with primary data were included.

Studies were screened initially based on titles and abstracts for data regarding NLIM using pre-defined inclusion and exclusion criteria. Only studies from countries of the Americas were included. Studies were excluded when reporting nonhuman studies, inconclusive data on mastitis and experimental and basic research approaches. The extracted data from the selected studies included the year of publication, geographical location, data on demography and epidemiology, breast imaging reporting and data system classification (BIRADS), histopathology, X-rays description, treatment, and relapse rates.

Data were described using descriptive statistics. A ShapiroWilk test was used to verify data distribution. Independent $t$-test, Wilcoxon Mann-Whitney and $\chi^{2}$ tests were used to compare patients from low, low-middle, and upper-middle-income (Latin American) countries and those from high-income countries (USA and Canada), accordingly. Significance was set as $p<0.05$. Analyses were performed using STATA ${ }^{\circledR}$ software, version 14 (Stata Corp., College Station, Texas).

\section{RESULTS}

The original search yielded a total of 4,297 potentially eligible studies. After the exclusion of duplicates, screening, and the use of predefined inclusion criteria, a total of 40 studies remained. Seven other studies were added after a reference search of the included studies. A total of 47 (25-71) studies and 93 patients were included (shown in Figure 1); 87 (94.6\%) were female, the mean age was $37(30-52)$, a history of pregnancy was reported in $24(26.1 \%)$, and 40 (43.5\%) presented risk factors (such chronic use of oral contraceptives, long-term steroid use, thoracic surgery, cat scratches, and among others) and/or other associated diseases (shown in Supplementary Table 1). Unilateral localization $(78 ; 83.9 \%)$ on the right breast $(46 ; 54.8 \%)$ was the most reported. Breast mass $(60 ; 65.2 \%)$ and abscess $(42$; $45.7 \%$ ) were the most reported clinical findings. One patient was asymptomatic. Table 2 describes other signs and symptoms.

The etiological agent was determined in $86(92.5 \%)$ patients. Bacteria were the most frequent etiology (73; 84.8\%). $M$. tuberculosis was isolated in $28(38.4 \%) ; 15(20.5 \%)$ by Corynebacterium spp.; and 13 cases $(17.8 \%)$ caused by NTM (shown in Table 2). Fungal (9; 10.5\%), viral (1; 1.2\%), or parasitic $(1 ; 1.2 \%)$ infections were also described. Sixty-six (71.0\%) patients underwent invasive procedures (drainage procedures, excisional biopsy, debridement, or resection), all of which combined with pharmacological treatment, except for 5 (5.6\%) patients (shown in Table 2). Primarily, epidemiological risk and biopsy results guided treatment. The majority of patients were treated with polypharmacotherapy (shown in Table 2).

Demographics, clinical, diagnostic features, and the causative infectious agent are available for 84 patients (shown in Table 3 ). Most cases were identified through biopsy alone (41; 48.8\%). Different signs and symptoms are related to distinct etiological agents. The median treatment time was 24 weeks (IQR: 424). The longest time to elucidate the diagnosis was in cases of tuberculous mastitis (TBM) with a median of 28 weeks (IQR: 16-32; shown in Table 3). Twenty-three cases (27.4\%) were of suspected breast cancer; among these, TBM caused 13 (46.4\%). Seventy-one (84.5\%) cases reported complete remission. Ten $(11.9 \%)$ relapses were described (shown in Table 3 and Supplementary Table 1). Different imaging methods were used alone or combined. Amongst these patients, 13 (15.5\%) individuals had abnormal chest X-rays, and 23 (27.4\%) were 
TABLE 1 | Search strategy of cases with non-lactational infectious mastitis in the Americas.

\begin{tabular}{ll}
\hline Database & Search strategy \\
\hline Scielo & Mastitis \\
Medline/Pubmed Lilacs & Mastitis AND (Americas OR Latin America OR North America OR South America OR Central America OR Antilles OR Anguilla OR \\
& Antigua OR Aruba OR Argentina OR Barbuda OR Belize OR Bahamas OR Barbados OR Bolivia OR Bonaire OR Brazil OR Canada \\
& OR Caribbean OR Chile OR Colombia OR Costa Rica OR Cuba OR Curacao OR Dominica OR Dominican Republic OR Ecuador OR \\
& El Salvador OR Grenada OR Grenadines OR Guadeloupe OR Guatemala OR Guyana OR Haiti OR Honduras OR Jamaica OR \\
& Martinique OR Mexico OR Montserrat OR Nevis OR Nicaragua OR Panama OR Paraguay OR Peru OR Puerto Rico OR Saint Kitts \\
& OR Saint Lucia OR Saint Vincent OR Suriname OR Surinam OR Trinidad OR Tobago OR United States of America OR USA OR \\
& Uruguay OR Venezuela)
\end{tabular}

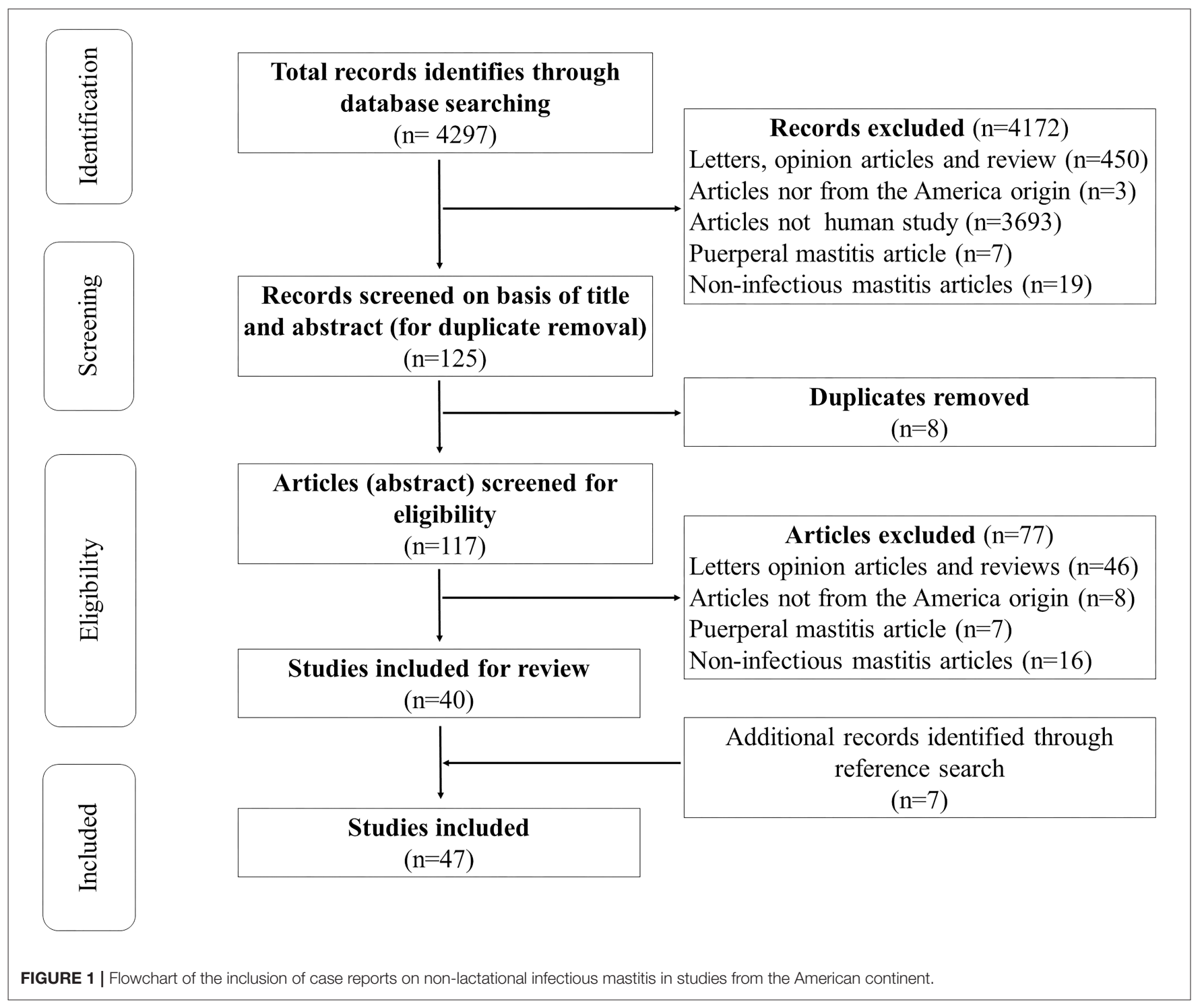

either classified as BI-RAD IV or BI-RAD V (shown in Table 3). A total of $78(83.9 \%)$ patients underwent biopsy. Granulomas $(65 / 78,83.3 \% ; 19$ were caseous and 46 non-caseous) and necrotic tissue $(32 / 78,41.0 \%)$ were the most prevalent findings. Other biopsy findings are presented in Supplementary Table 1.
The cases were reported in eight different countries, mostly from the USA (35, 37.6\%; shown in Figure 2). The LatinAmerican countries reported a more significant number of TBM and NTM cases. Fungi, Corynebacterium spp., and other different bacteria were more frequent in the USA/Canada 
TABLE 2 | Clinical findings of cases, etiology, and treatment of non-lactational infectious mastitis in the Americas.

\begin{tabular}{|c|c|c|}
\hline Variables & Total $n(\%)$ & Cl $95 \%$ \\
\hline \multicolumn{3}{|l|}{ Clinical findings } \\
\hline \multicolumn{3}{|c|}{ Signs and symptoms previous to hospitalization $(n=92)^{a}$} \\
\hline Breast mass & $60(65.2)$ & $0.546-0.749$ \\
\hline Abscess & $42(45.7)$ & $0.352-0.564$ \\
\hline Fistula & $21(22.8)$ & $0.147-0.328$ \\
\hline Breast hardness & $11(13.2)$ & $0.061-0.204$ \\
\hline Fever & $9(9.8)$ & $0.046-0.178$ \\
\hline Nipple discharge & $8(8.7)$ & $0.038-0.164$ \\
\hline Isolated breast pain & $4(4.3)$ & $0.012-0.108$ \\
\hline Ulcer & $4(4.3)$ & $0.012-0.108$ \\
\hline Breast implant exhibition & $3(3.9)$ & $0.007-0.092$ \\
\hline Blisters & $1(1.3)$ & $0.001-0.059$ \\
\hline Asymptomatic & $1(1.3)$ & $0.001-0.059$ \\
\hline \multicolumn{3}{|l|}{ Breast of occurrence $(n=84)$} \\
\hline Right & $46(54.8)$ & $0.435-0.657$ \\
\hline Left & $32(38.1)$ & $0.277-0.493$ \\
\hline Bilateral & $6(7.1)$ & $0.027-0.149$ \\
\hline \multicolumn{3}{|l|}{ Breast quadrant $(n=29)$} \\
\hline Upper-outer & $7(24.1)$ & $0.103-0.435$ \\
\hline Upper-inner & $4(13.8)$ & $0.039-0.317$ \\
\hline Lower-outer & $3(10.3)$ & $0.022-0.274$ \\
\hline Lower-inner & $6(20.7)$ & $0.080-0.397$ \\
\hline More than one quadrant & $9(31.0)$ & $0.153-0.508$ \\
\hline \multicolumn{3}{|l|}{ ETIOLOGY $(n=86)$} \\
\hline Bacteria & $73(84.8)$ & $0.755-0.917$ \\
\hline Mycobacterium tuberculosis & $28(38.4)$ & $0.272-0.505$ \\
\hline Corynebacterium spp. & $15(20.5)$ & $0.120-0.316$ \\
\hline Non-tuberculous mycobacteria & $13(17.8)$ & $0.098-0.285$ \\
\hline Mycobacterium fortuitum & $3(23.1)$ & $0.050-0.538$ \\
\hline Mycobacterium abscessus & $2(15.4)$ & $0.019-0.454$ \\
\hline Mycobacterium avium & $2(15.4)$ & $0.019-0.454$ \\
\hline Mycobacterium chelonae & $1(7.7)$ & $0.002-0.360$ \\
\hline Mycobacterium mucogenicum & $1(7.7)$ & $0.002-0.360$ \\
\hline Not specified & $4(30.8)$ & $0.091-0.614$ \\
\hline Other bacteria ${ }^{b}$ & $17(23.3)$ & $0.142-0.346$ \\
\hline Fungi & $9(10.5)$ & $0.049-0.189$ \\
\hline Histoplasma spp. & $3(33.3)$ & $0.075-0.700$ \\
\hline Blastomyces spp. & $2(22.2)$ & $0.028-0.600$ \\
\hline Cryptococcus neoformans & $2(22.1)$ & $0.028-0.600$ \\
\hline Paracoccidioides brasiliensis & $1(11.1)$ & $0.002-0.482$ \\
\hline Histoplasma sp./Paracoccidioides sp. & $1(11.1)$ & $0.002-0.482$ \\
\hline Virus: Herpes simplex & $1(1.2)$ & $0.001-0.063$ \\
\hline Parasite: Sparganum sp. & $1(1.2)$ & $0.001-0.063$ \\
\hline Normal cutaneous flora & $1(1.2)$ & $0.001-0.063$ \\
\hline Not specified & $1(1.2)$ & $0.001-0.063$ \\
\hline \multicolumn{3}{|l|}{ TREATMENT } \\
\hline \multicolumn{3}{|l|}{ Treatment approach $(n=90)$} \\
\hline Only pharmacological therapy & $24(26.7)$ & $0.179-0.125$ \\
\hline $\begin{array}{l}\text { Pharmacological therapy combined with } \\
\text { drainage/surgical procedures }\end{array}$ & $61(67.8)$ & $0.571-0.772$ \\
\hline
\end{tabular}

(Continued)
TABLE 2 | Continued

\begin{tabular}{lcc}
\hline Variables & Total $\boldsymbol{n}(\%)$ & Cl $95 \%$ \\
\hline $\begin{array}{l}\text { Only Surgical treatment } \\
\text { Pharmacological drugs }(\boldsymbol{n}=\mathbf{8 4})\end{array}$ & $5(5.6)$ & $0.018-0.125$ \\
Pharmacological polytherapy & $49(58.3)$ & \\
Pharmacological monotherapy & $24(28.6)$ & $0.471-0.690$ \\
Not specified & $11(13.1)$ & $0.067-0.222$ \\
Pharmacological group $(\boldsymbol{n}=\mathbf{7 4})$ & & \\
Antituberculous agents & $30(40.5)$ & $0.293-0.526$ \\
Fluoroquinolones & $9(12.2)$ & $0.057-0.218$ \\
Macrolides & $8(10.8)$ & $0.048-0.202$ \\
Sulfonamides & $7(9.5)$ & $0.039-0.185$ \\
Tetracyclines & $7(9.5)$ & $0.039-0.185$ \\
Antifungal agents & $6(8.1)$ & $0.030-0.168$ \\
Beta-lactams & $6(8.1)$ & $0.030-0.168$ \\
Cephalosporins & $6(8.1)$ & $0.030-0.168$ \\
Lincosamides & $5(6.8)$ & $0.022-0.151$ \\
Corticosteroids & $4(5.4)$ & $0.015-0.133$ \\
Penicillins & $4(5.4)$ & $0.015-0.133$ \\
Immunomodulators & $3(4.1)$ & $0.008-0.114$ \\
Aminoglycosides & $2(2.7)$ & $0.003-0.094$ \\
Oxazolidinones & $2(2.7)$ & $0.003-0.094$ \\
Antiviral agents & $1(1.4)$ & $0.001-0.073$ \\
Anti-inflamatories & $1(1.4)$ & $0.001-0.073$ \\
Hydroxychloroquine & $1(1.4)$ & $0.001-0.073$ \\
Lipopeptides & $1(1.4)$ & $0.001-0.073$ \\
\hline a & & \\
\hline
\end{tabular}

${ }^{a}$ No signs or symptoms were available in 1 patient; ${ }^{b}$ Staphylococcus sp.: $n=4$; Grampositive bacteria $n=3$; Actinomyces sp.: $n=2$; Gram-Negative bacteria $n=2$ : Fusobacterium sp.: $n=2$; Finegoldia magna: $n=1$; Propionibacterium acne: $n=1$; Acinetobacter baumannii: $n=1$; Aeromonas hydrophila: $n=1$. The bold values mean the main etiology groups.

group (shown in Table 3 and Figure 2). When comparing the two groups of countries categorized by their annual GNI per capita (shown in Table 4), a statistically significant difference was established in terms of the sex most affected by NLIM, the feminine sex $(p=0.044)$. Patients from the high-income countries presented a shorter diagnostic time than low-middle and upper-middle-income countries $(p=0.017)$. Radiographic studies with pathological findings were more described in highincome countries $(p=0.004)$. The diagnosis was confirmed by biopsy in a more significant percentage in Latin American countries $(p=0.029)$.

\section{DISCUSSION}

This study describes the epidemiology, clinical aspects, diagnostics, management, and etiological agents of reported NLIM and compares subjects regarding their country's GNI per capita. Female patients of reproductive age are the most affected by NLIM $(17,72)$, and only a few reviews have reported cases in men $(73,74)$. In terms of age and sex distribution, the findings in this study coincide with the prevalence reported (92.9\% female) in a study on breast tuberculosis in the Republic of Togo (73).

NLIM is characterized by local inflammatory symptoms and a generally unilateral breast mass, as reported by different 
TABLE 3 | Demographic and clinical characteristics of NLIM patients infected with different pathogens.

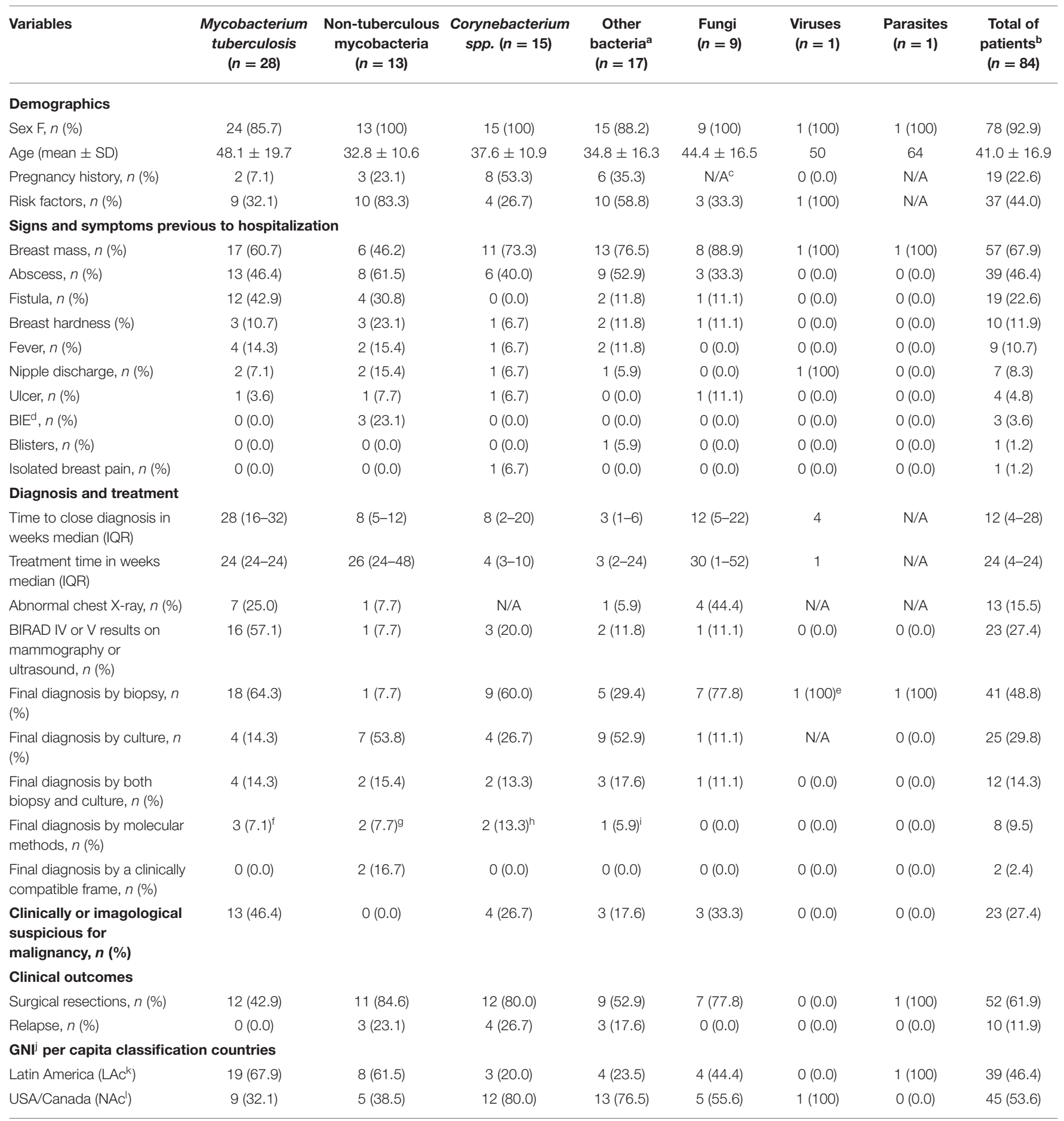

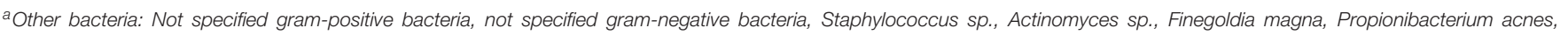

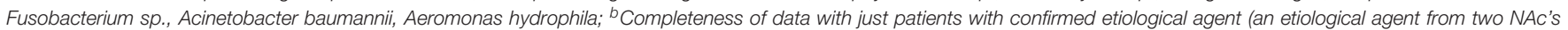

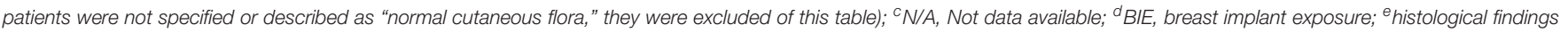

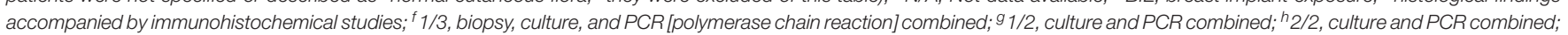
${ }^{i} 1 / 1$, culture and PCR combined; ' GNI, gross national income; ${ }^{k} L A c$, Latin-American countries; 'NAc, North American countries.

studies from Asia and Europe (74-76). Both breast mass and unilateral lesions were found with similar prevalence in this study, although abscess was the most frequent clinical manifestation in Latin American countries. Nair et al. (17) conducted a retrospective study in India in which no case was clinically or radiologically suspected of 


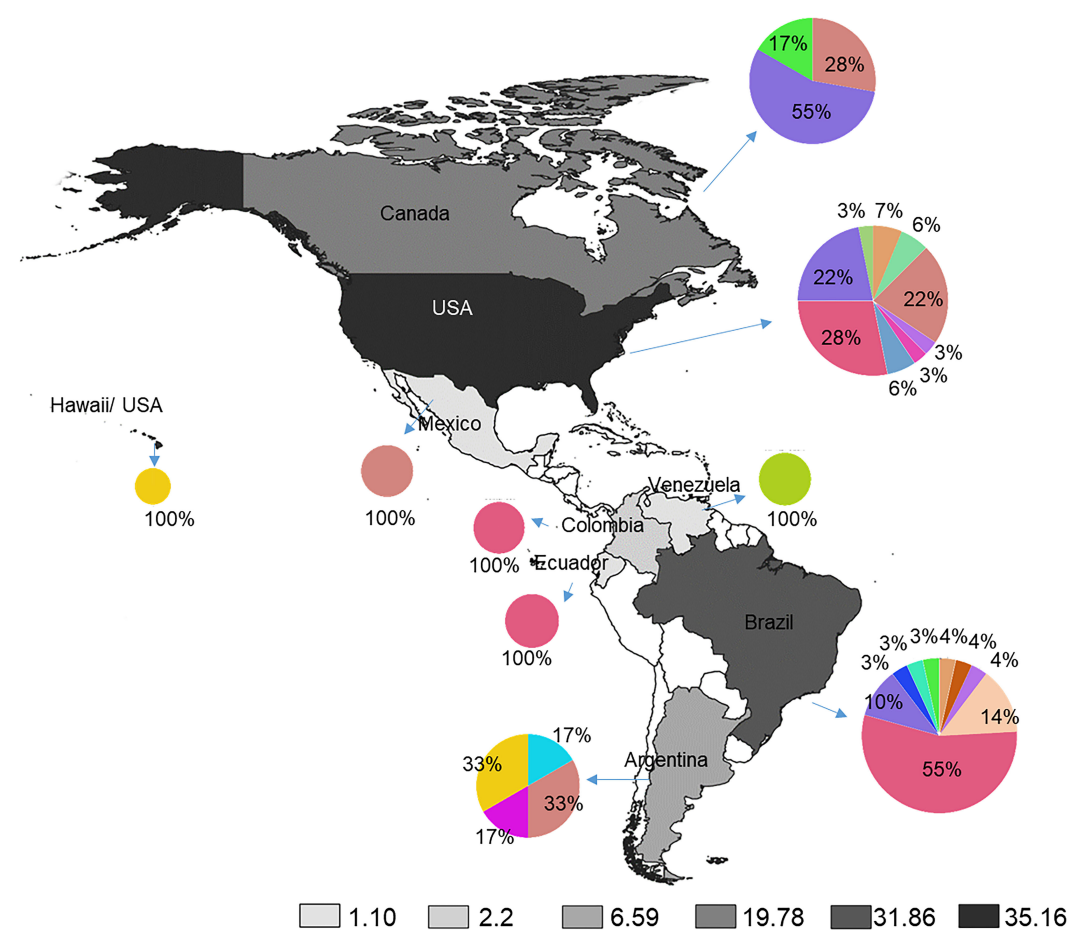

Acinetobacter baumani

Aeromonas hydrophila

Blastomyces sp.

Corynebacterium sp.

Cryptococcus neoformans

Finegoldia magna

Herpes

Histoplasma sp.

Histoplasma $\mathrm{sp}+$ Paracoccidioides $\mathrm{sp}$

Non-tuberculose mycobacteria

Mycobacterium tuberculosis

Outras bacterias

Paracoccidioides brasiliensis

Proprionibacterium acnes

Sparganum

Staphylococcus sp

FIGURE 2 | The prevalence of non-lactational infectious mastitis in American countries and the register of etiological infection agents.

TABLE 4 | Population characteristics, clinical, diagnostic management, and treatment according to high and middle/low-income countries.

\begin{tabular}{|c|c|c|c|c|c|}
\hline Variables & All $(n=92)$ & $\begin{array}{l}\text { High-income countries } \\
\text { group }(n=52)\end{array}$ & $\begin{array}{l}\text { Low, low-middle, and } \\
\text { upper-middle-income } \\
\text { countries }(n=40)\end{array}$ & $\begin{array}{l}\text { Completeness } \\
\qquad N(\%)\end{array}$ & $p$-value \\
\hline \multicolumn{6}{|l|}{ Demographics } \\
\hline Sex $F, n(\%)$ & $87(94.6)$ & $47(90.4)$ & $40(100)$ & $92(100)$ & 0.044 \\
\hline Age median(IQR) & 37 (30-52) & $37(30-50)$ & $38(29-54)$ & $91(98.9)$ & 0.774 \\
\hline Pregnancy history, $n$ (\%) & $24(26.1)$ & $21(40.4)$ & $3(7.5)$ & $36(39.1)$ & 0.074 \\
\hline Risk factors, $n(\%)$ & $40(43.5)$ & $25(48.1)$ & $15(37.5)$ & $58(63.0)$ & 0.760 \\
\hline \multicolumn{6}{|l|}{ Diagnosis and treatment } \\
\hline Time to close diagnosis in weeks median (IQR) & $14(4-28)$ & $8(4-20)$ & $24(8-32)$ & $60(65.2)$ & 0.017 \\
\hline Treatment time in weeks median (IQR) & $24(4-28)$ & $24(3-36)$ & $24(24-24)$ & $65(70.7)$ & 0.188 \\
\hline Abnormal Chest X-ray, $n(\%)$ & $13(14.1)$ & $9(17.3)$ & $4(10.0)$ & $40(43.5)$ & 0.004 \\
\hline Confirmed microorganism, $n$ (\%) & $85(92.4)$ & $46(88.5)$ & $39(97.5)$ & $92(100)$ & 0.105 \\
\hline Final diagnosis by Biopsy, $n(\%)$ & $42(45.7)$ & $21(40.4)$ & $21(52.5)$ & $74(80.4)$ & 0.029 \\
\hline Final diagnosis by Culture, $n(\%)$ & $25(27.2)$ & $15(28.8)$ & $10(25.0)$ & $54(58.7)$ & 0.675 \\
\hline $\begin{array}{l}\text { Clinically or imagological suspicious for } \\
\text { malignancy, } n(\%)\end{array}$ & $24(26.1)$ & $14(26.9)$ & $10(25.0)$ & $88(95.7)$ & 0.965 \\
\hline Surgical resections, $\boldsymbol{n}(\%)$ & $59(64.1)$ & $38(73.1)$ & $21(52.5)$ & $89(96.7)$ & 0.028 \\
\hline Relapse, $n(\%)$ & $11(12.0)$ & $9(17.3)$ & $2(5.0)$ & $87(94.6)$ & 0.057 \\
\hline
\end{tabular}

The bold values mean that they are statistically significant.

being malignant, which differs from findings reports in the present study.

The diagnosis of NLIM remains a significant challenge for clinicians in the Americas. The duration of signs and symptoms before a definitive diagnosis may vary significantly. Time to diagnosis was longer in countries of low and middle-GNI per capita in this report compared to those from Asian and European countries $(17,75)$. A possible reason for this situation could be the lack of clinical suspicion by health-care professionals or the lack of adequate diagnostic techniques $(13,77)$, especially when 
comparing the numbers of cases reported in countries of the European continent (78). In addition, culturally related barriers to reproductive health, including breast care, may interfere with the results described in this review (79-81).

Overall, most imaging studies aim to delimitate breast lesions or rule out possible pathologies of malignant origin. Few articles reported the use of imaging techniques for diagnostic purposes on breast infection $(82,83)$. The number of patients that underwent mammography in this manner (32.3\%) was higher than the data described (17.9\%) in a Chinese hospital (83). However, the percentage of ultrasound exams was lower than the reported in a Turkish study, in which $100 \%$ of the patients underwent ultrasound (82). The use of lowcost imaging techniques, such as ultrasonography, could be an interesting first-line approach for such use in low- and middle-income countries.

The histopathological investigation was the most reliable pathogen identification tool. Granuloma was the most frequent description among patients undergoing a biopsy, which was higher than the one found (21\%) in an Indian study on tuberculous mastitis (74). Almost half the cultures in this review reported microorganisms, which was lower than an Irish cohort (88.9\%) of cases of NLIM (9). Also, the number of positive cultures in patients from the USA and Canada was higher than in Latin-Americans.

Milk stasis can facilitate the development of lactational mastitis which, together with the gastrointestinal and skin microbiota of the mother and infant, increases the risk of appearance of it (19), however, the most frequent etiological causes of lactational and non-lactational mastitis are led by grampositive organisms (9). In the Asian continent, Staphylococcus aureus was the leading etiologic cause of non-lactating breast infections $(8,84)$. In this review, Mycobacterium tuberculosis was responsible for the most cases, and although tuberculous mastitis was first described in the 19th century (85) and is considered a rare clinical presentation, it is estimated to occur in up to $4 \%$ of patients in endemic countries (86), suggesting the persistence of tuberculosis in the Americas as a public health problem, and since many articles conducted in the Americas focus on tuberculous or granulomatous mastitis $(6,12,87)$, it is not surprising that $M$. tuberculosis figures as an important cause of NLIM. Other nontuberculous mycobacteria may also cause NLIM, as previously reported in India and England (88, 89). Likewise, NLIM cases caused by Corynebacterium spp. were reported in Europe $(90,91)$, both of which were described as the leading causes of mastitis in this review. In 1990, Edmiston et al. (22) also reported other etiological agents that were correlated as other etiological agents of NLIM.

The length of treatment depends on the underlying infectious cause. Several case reports lacked data on the duration of treatment. The treatment time for TM was slightly more than eight months in a Korean study by Seo et al. (13). However, our findings depicted a longer treatment time for this pathology in countries from the Americas. This was similar for Corynebacterium spp. infections compared to data from a study conducted in New Zealand (11).
Different management approaches were also found in this study. In a Turkish study, 12 (38\%) patients were only treated with surgery, while one (3.2\%) was treated with medication (92). In contrast, in our findings, a lower number of cases underwent surgery, and the majority to antimicrobial drugs. Other cases required treatment with a combination of drug therapy and drainage procedures. A more significant amount of patients were treated similarly (9). Overall, patients were prescribed medications from different pharmacological groups, which varied according to the etiological agent and clinical presentation. This variety of drugs has also been reported in Saudi Arabia, where S. aureus was the most prevalent etiological agent (84).

Cases of NLIM relapse have been reported in European countries in $11-38.3 \%$ of cases $(9,15)$. The relapse rate obtained in this study was very similar. Most patients in our series reside in high-income countries, and none of them was in the TM group. This may be explained by the fact that recurrences of TM are rare since treatment usually produces a definitive cure $(13,75)$. Moreover, gram-positive bacteria, such as Corynebacterium spp., and gram-negative bacteria were more prevalent in patients from the USA and Canada, with such cases presenting a significant number of relapses (72).

This study has several limitations: infrequent clinical presentations are more likely to be published, leading to publication bias, and undermining real-life prevalence estimation and clinical depiction.; also, assessing disease prevalence or clinical outcomes among several studies with different designs, hypotheses, objectives, methodologies may lead to a lack of data standardization, which is an expected limitation to this type of study; these may also affect case management, which may have further influenced the results of the present study; and finally, the lack of systematic reporting from the included studies hampers comprehensive data analysis and completeness.

\section{CONCLUSION}

NLIM is a complex disease and presents difficulties in diagnosis and treatment due to various confounding factors as epidemiological, etiological, and clinical aspects. This study summarizes the different epidemiological and clinical aspects of NLIM on the American continent. Tuberculous mastitis, NTM, and cystic neutrophilic granulomatous mastitis (CNGM) due to Corynebacterium spp. were the leading infectious causes of NLIM. No publication has described the many facets and features of NLIM in both the Latin American and high-income American countries. Despite a paucity of references discussing NLIM, the results reported in this study demonstrate that it remains a public health problem. The long period from the onset of symptoms to diagnosis shows the importance of a multi-professional approach. Prospective cohorts are necessary to have a greater 
comprehension of the NLIM, including remote locations such as the Amazon.

\section{DATA AVAILABILITY STATEMENT}

The raw data supporting the conclusions of this article will be made available by the authors, without undue reservation.

\section{AUTHOR CONTRIBUTIONS}

VC, MC-S, ML, and FV: study concept and design. VC, NC-V, PL, and DB-d-S: acquisition of the data. VC, NV, DB-d-S, and FV: analysis of the data. VC, NC-V, PL, DB-d-S, and FV: drafting of the manuscript. VC, NC-V, PL, DB-d-S, MA, IP, MC-S, ML, and FV: critical revision of the manuscript and approval of final manuscript. All authors contributed to the article and approved the submitted version.

\section{REFERENCES}

1. Amir LH. ABM Clinical Protocol \#4: Mastitis, Revised March 2014. Breastfeed Med. (2014) 9:239-43. doi: 10.1089/bfm.2014.9984

2. Boakes E, Woods A, Johnson N, Kadoglou N. Breast infection: a review of diagnosis and management practices. Eur J Breast Heal. (2018) 14:13643. doi: 10.5152/ejbh.2018.3871

3. Inch S, Xylander S, Savage F. Mastitis Causes and Mangaement. Geneva: WHO/FCH/CA, World Health Organization (2000).

4. Boccaccio C, Verdaguer V, Botto L, Cervetto M, Cetani S, Paladino S, et al. Aislamiento de Staphylococcus aureus meticilino Resistente en Abscesos de mama en una Maternidad Pública. Medicina (B Aires). (2014) 74:210-5.

5. Cusack L, Brennan M. Lactational mastitis and breast abscess: diagnosis and management in general practice. Aust Fam Physician. (2011) 40:976-9.

6. Joseph KA, Luu X, Mor A. Granulomatous mastitis: a New York public hospital experience. Ann Surg Oncol. (2014) 21:4159-63. doi: 10.1245/s10434-014-3895-Z

7. Contreras GA, Rodríguez JM. Mastitis: comparative etiology and epidemiology. J Mammary Gland Biol Neoplasia. (2011) 16:339-56. doi: 10.1007/s10911-011-9234-0

8. Ramakrishnan R, Trichur RV, Murugesan S, Cattamanchi S. Analysis of the microbial flora in breast abscess: a retrospective cohort study conducted in the emergency department. Int Surg J. (2017) 4:2143. doi: 10.18203/2349-2902.isj20172599

9. Russell SP, Neary C, Abd Elwahab S, Powell J, O'Connell N, Power L, et al. Breast infections - microbiology and treatment in an era of antibiotic resistance. Surgeon. (2019) 18:1-7. doi: 10.1016/j.surge.2019.03.008

10. Sandhu GS, Gill HS, Sandhu GK, Gill GP, Gill AK. Bacteriology in breast abscesses. Sch J Appl Med Sci. (2014) 2:1469-72.

11. Paviour S, Musaad S, Roberts S, Taylor G, Taylor S, Shore K, et al. Corynebacterium species isolated from patients with mastitis. Clin Infect Dis. (2002) 35:1434-40. doi: 10.1086/344463

12. Tafur K, Cáceres J, Accinelli R. Características clínicas y anatomo-patológicas de las pacientes que ingresaron al Programa de Control de Tuberculosis con diagnóstico de tuberculosis de mama. Rev Medica Hered. (2016) 25:215. doi: $10.20453 /$ rmh.v25i4.2180

13. Seo HRN, Na KY, Yim HE, Kim TH, Kang DK, Oh KK, et al. Differential diagnosis in idiopathic granulomatous mastitis and tuberculous mastitis. $J$ Breast Cancer. (2012) 15:111-8. doi: 10.4048/jbc.2012.15.1.111

14. Padoveze MC, Fortaleza CMCB, Freire MP, Brandão de Assis D, Madalosso G, Pellini ACG, et al. Outbreak of surgical infection caused by non-tuberculous mycobacteria in breast implants in Brazil. J Hosp Infect. (2007) 67:1617. doi: 10.1016/j.jhin.2007.07.007

\section{FUNDING}

This study was supported by the Coordenação de Aperfeięoamento de Pessoal de Nível Superior (CAPES), and the Fundação de Amparo à Pesquisa do Estado do Amazonas (FAPEAM) RESOLUÇÃO N. 002/2008, 007/2018 e 005/2019 - PRÓ-ESTADO and RESOLUÇÃO N. 006/2020 - POSGRAD 2020. ML is a CNPq (Conselho Nacional de Desenvolvimento Científico e Tecnológico) fellow. The funders had no role in study design, data collection, manuscript preparation, or decision to publish.

\section{SUPPLEMENTARY MATERIAL}

The Supplementary Material for this article can be found online at: https://www.frontiersin.org/articles/10.3389/fmed. 2021.672513/full\#supplementary-material

15. Taffurelli M, Pellegrini A, Santini D, Zanotti S, Di Simone D, Serra M. Recurrent periductal mastitis: surgical treatment. Surg (United States). (2016) 160:1689-92. doi: 10.1016/j.surg.2016.06.048

16. Dixon JM, Khan LR. Treatment of breast infection. BMJ. (2011) 342:4849. doi: 10.1136/bmj.d396

17. Gopalakrishnan Nair C, Hiran, Jacob P, Menon RR, Misha. Inflammatory diseases of the non-lactating female breasts. Int J Surg. (2015) 13:811. doi: 10.1016/j.ijsu.2014.11.022

18. Michie C, Lockie F, Lynn W. The challenge of mastitis. Arch Dis Child. (2003) 88:818-21. doi: 10.1136/adc.88.9.818

19. Angelopoulou A, Field D, Ryan CA, Stanton C, Hill C, Ross RP. The microbiology and treatment of human mastitis. Med Microbiol Immunol. (2018) 207:83-94. doi: 10.1007/s00430-017-0532-Z

20. Janes SE, Lengyel JA, Singh S, Aluwihare N, Isgar B. Needle core biopsy for the assessment of unilateral breast masses in men. Breast. (2006) 15:2735. doi: 10.1016/j.breast.2005.05.003

21. Rajagopala S, Agarwal R. Tubercular mastitis in Men: case report and systematic review. Am J Med. (2008) 121:53944. doi: 10.1016/j.amjmed.2008.01.026

22. Edmiston CE, Walker AP, Krepel CJ, Gohr C. The nonpuerperal breast Infection: aerobic and anaerobic microbial recovery from acute and chronic disease. J Infect Dis. (1990) 162:695-9. doi: 10.1093/infdis/162.3.695

23. Kamal RM, Hamed ST, Salem DS. Classification of inflammatory breast disorders and step by step diagnosis. Breast J. (2009) 15:367-80. doi: 10.1111/j.1524-4741.2009.00740.x

24. Moher D, Liberati A, Tetzlaff J, Altman DG, Altman D, Antes $\mathrm{G}$, et al. Preferred reporting items for systematic reviews and meta-analyses: the PRISMA statement. PLoS Med. (2009) 6:e1000097. doi: 10.1371/journal.pmed.1000097

25. Al-Qattan MM, Robertson GA. Bilateral chronic infection of the lactosebaceous glands of montgomery. Ann Plast Surg. (1990) 25:491-3. doi: 10.1097/00000637-199012000-00012

26. Arango-Ferreira C, Zapata-Muñoz CM, Gotuzzo E. Images in clinical tropical medicine: cutaneous tuberculosis presenting as mastitis in a prepubertal girl. Am J Trop Med Hyg. (2018) 99:1360-1. doi: 10.4269/ajtmh.18-0413

27. Da Silva BB, Dos Santos LG, Costa PVL, Pires CG, Borges AS. Clinical case report: primary tuberculosis of the breast mimicking carcinoma. Am J Trop Med Hyg. (2005) 73:975-6. doi: 10.4269/ajtmh.2005.73.975

28. Da Silva BB, Lopes-Costa PV, Pires CG, Pereira-Filho JD, dos Santos AR. Tuberculosis of the breast: analysis of 20 cases and a literature review. Trans $R$ Soc Trop Med Hyg. (2009) 103:559-63. doi: 10.1016/j.trstmh.2009.02.005

29. Fernandez LV, Fortuny AS, Rodriguez EF. Corynebacterium pyruviciproducens and Corynebacterium amycolatum mastitis in 
immunocompetent no breastfeeding women. Rev Argent Microbiol. (2020) 53:4-7. doi: 10.1016/j.ram.2020.06.006

30. Fred HL. An enlarging breast mass in an HIV-seropositive woman. Hosp Pract. (1995) 30:31-2. doi: 10.1080/21548331.1995.11443196

31. Gamblin TC, Nobles-James C, Bradley RA, Katner HP, Dale PS. Cat scratch disease presenting as breast mastitis. Can J Surg. (2005) 48:254-5.

32. García-Lozano T. Lesiones vesículo-ampollosas en un paciente oncológico inmunodeprimido Vesiculobullous lesions in an immunocompromised cancer patient. Rev Argent Microbiol. (2012) 31:46009. doi: 10.1590/S0325-75412012000100011

33. Goldman M, Pottage JC. Cryptococcal infection of the breast. Clin Infect Dis. (1995) 21:1166-9. doi: 10.1093/clinids/21.5.1166

34. Hale JA, Peters GN, Cheek JH. Tuberculosis of the breast: rare but still extant. Am J Surg. (1985) 150:620-4. doi: 10.1016/0002-9610(85)90450-7

35. Johnson M, Plongla R, Leone P, Gilligan P. The brief case: recurrent granulomatous mastitis due to Corynebacterium kroppenstedtii. J Clin Microbiol. (2016) 54:1938-41. doi: 10.1128/JCM.03131-15

36. Kamyab A. Granulomatous lobular mastitis secondary to Mycobacterium fortuitum. World J Clin Cases. (2016) 4:409. doi: 10.12998/wjcc.v4.i12.409

37. Bhatty O, Waters D, Wilka N, Samuel S, Horne J, Vivekanandan R. A rare manifestation of tuberculosis presenting in the United States. Case Rep Infect Dis. (2016) 2016:1-4. doi: 10.1155/2016/8216040

38. Krueger K, Guggina LM. Mycobacterium mucogenicum skin and soft tissue infection of the breast mimicking idiopathic granulomatous mastitis. BMJ Case Rep. (2019) 12:10-3. doi: 10.1136/bcr-2019-231900

39. Trang D, Damania Z, Tschetter CN, Lehman NL. Case report. J Fam Pract. (2017) 66:38-41.

40. Lizaso D, García M, Aguirre A, Esposto A. Infección protésica mamaria por Mycobacterium fostuitum em una paciente con lupus eritematoso sistémico. Rev Chil Infectol. (2011) 28:474-8. doi: 10.4067/S0716-10182011000 600013

41. Maung MH, Bethune GC, Patriquin G, Barnes PJ. Cystic neutrophilic granulomatous mastitis - a review of 12 consecutive cases. Histopathology. (2020) 77:781-7. doi: 10.1111/his.14187

42. Merino-Alado R, Pineda J, Rasquin JH, Landaeta ME, Mata-Essayag S. Granulomatous mastitis due to coinfection with Histoplasma sp. and Paracoccidioides sp.: A case report. Med Mycol Case Rep. (2020) 27:524. doi: 10.1016/j.mmcr.2020.01.006

43. Mohr E, Berhane A, Zora JG, Suchdev P. Acinetobacter baumannii neonatal mastitis: a case report. J Med Case Rep. (2014) 8:1-3. doi: 10.1186/1752-1947-8-318

44. Moreira MAR, de Freitas R, Gerais BB. Granulomatous mastitis caused by sparganum. Acta Cytol. (1997) 41:859-62. doi: 10.1159/000332717

45. Palmero DJ, Ambroggi MG, Poggi SE, Muñiz HFJ, Aires B. Mastitis por Mycobacterium fortuitum en una paciente HIV negativa. Medicina (B Aires). (2004) 64:529-32.

46. Payne S, Kim S, Das K, Mirani N. A 36-year-old woman with a unilateral breast mass. Arch Pathol Lab Med. (2006) 130:1-2. doi: 10.5858/2006-130-e1-AYWWAU

47. Pereira LH, Sterodimas A. Autologous fat transplantation and delayed silicone implant insertion in a case of Mycobacterium avium breast infection. Aesthetic Plast Surg. (2010) 34:1-4. doi: 10.1007/s00266-009-9357-5

48. Bianco SR, Gurgel RL, Tavares MDA. Aspectos radiológicos da tuberculose primária da mama: relato de caso e revisão de literatura. Rev Soc Bras Med Trop. (2009) 42:203-5. doi: 10.1590/S0037-86822009000200022

49. Ramos-barbosa S, Guazzelli LS. Criptococose mamária manifesta após corticoterapia Cryptococcal mastitis after corticosteroid therapy. Rev Soc Bras Med Trop. (2004) 37:65-6. doi: 10.1590/S0037-86822004000100018

50. Qiao Y, Hayward JH, Balassanian R, Ray KM, Joe BN, Lee AY. Tuberculosis mastitis presenting as bilateral breast masses. Clin Imaging. (2018) 52:2831. doi: 10.1016/j.clinimag.2018.02.013

51. Reyes CV, Thompson KS, Jensen J. Fine needle aspiration biopsy of mastitis secondary to empyema necessitatis. Acta Cytol. (1999) 43:8736. doi: 10.1159/000331307

52. Renshaw AA, Derhagopian RP, Gould EW. Cystic neutrophilic granulomatous mastitis: an underappreciated pattern strongly associated with gram-positive bacilli. Am J Clin Pathol. (2011) 136:424-7. doi: 10.1309/AJCP1W9JBRYOQSNZ
53. Salfelder K. Mycotic "pseudotumors" of the breast. Report of four cases. Arch Surg. (1975) 110:751-4. doi: 10.1001/archsurg.1975.01360120069013

54. Sánchez-Miño JI, Ortíz AM, Orozco L, Venegas B, Yepez F, Escalona-Rabaza M. Tuberculosis de mama: Reporte de un Caso. Rev Peru Med Exp Salud Publica Tuberc. (2018) 35:333-7. doi: 10.17843/rpmesp.2018.352.3131

55. Shoyele O, Vidhun R, Dodge J, Cheng Z, Margules R, Nee P, et al. Cystic neutrophilic granulomatous mastitis: a clinicopathologic study of a distinct entity with supporting evidence of a role for Corynebacterium-targeted therapy. Ann Diagn Pathol. (2018) 37:51-6. doi: 10.1016/j.anndiagpath.2018.08.005

56. Silva WA, Pinheiro AM, Jahns B, Bögli-Stuber K, Droz S, Zimmerli S. Breast abscess due to Actinomyces europaeus. Infection. (2011) 39:2558. doi: 10.1007/s15010-011-0119-3

57. Soo MS, Ghate S. Herpes simplex virus mastitis. Am J Roentgenol. (2000) 174:1087-8. doi: 10.2214/ajr.174.4.1741087

58. Stary CM, Lee YS, Balfour J. Idiopathic granulomatous mastitis associated with Corynebacterium sp. infection. Hawaii Med J. (2011) 70:99-101.

59. Brickman M, Parsa AA, Parsa FD. Mycobacterium cheloneae infection after breast augmentation. Aesthetic Plast Surg. (2005) 29:116-8. doi: 10.1007/s00266-004-0023-7

60. Thompson KS, Donzelli J, Jense J, Pachucki C, Eng AM, Reyes CV. Breast and cutaneous mycobacteriosis: diagnosis by fine-needle aspiration biopsy. Diagn Cytopathol. (1997) 17:459. doi: 10.1002/(SICI)1097-0339(199707)17:1<45::AID-DC9>3.0.CO;2-O

61. Trupiano JK, Sebek BA, Goldfarb J, Levy LR, Hall GS, Procop GW. Mastitis due to Mycobacterium abscessus after body piercing. Clin Infect Dis. (2001) 33:131-4. doi: 10.1086/320885

62. Trop I, Dugas A, David J, Khoury ME, Boiuleau J-F, Larouche N, et al. Breast abscesses: evidence-based algorithms for diagnosis, management, and follow-up. Radiographics. (2011) 31:1683-99. doi: 10.1148/rg.316115521

63. Vanek J, Schwarz J, Hakim S. North American blastomycosis: a study of ten cases. Am J Clin Pathol. (1970) 54:384-400. doi: 10.1093/ajcp/54.3.384

64. Wajnberg GB, Basile VVD, Prado LGM, Faria J de, Radwanski HN, Pitanguy I. Mycobacteriosis in patients with breast implants: a case review from the Ivo Pitanguy Institute. Rev Bras Cir Plástica. (2011) 26:4827. doi: 10.1590/S1983-51752011000300019

65. Wilson JP, Chapman SW. Tuberculous mastitis. Chest J. (1990) 98:15059. doi: 10.1378/chest.98.6.1505

66. Wang L, Jorns JM. Cystic neutrophilic granulomatous mastitis: Corynebacterium species-associated infection with distinct histology. Clin Microbiol Infect. (2020) 27:236-7. doi: 10.1016/j.cmi.2020.06.037

67. Castello L, Bou M, Bazzana MS, Predari SC. Absceso mamario no puerperal por Finegoldia magna. Rev Argent Microbiol. (2007) 39:95-8.

68. Chambô Filho A, Borges FLL, Cintra LC, Martins RM. Mastite por paracoccidioidomicose: relato de caso. Rev Bras Ginecol Obs. (2000) 22:5936. doi: 10.1590/S0100-72032000000900009

69. Conde DM. Treatment approach for breast abscess in nonlactating adolescents. Int J Gynecol Obstet. (2015) 128:723. doi: 10.1016/j.ijgo.2014.08.009

70. Cuervo SI, Bonilla DA, Murcia MI, Hernández J, Gómez JC. Mastitis tuberculosa. Biomédica. (2013) 33:36-41. doi: 10.7705/biomedica.v33i1.1426

71. Cunningham CO, Selwyn PA. Case report: mastitis due to Mycobacterium avium complex in an HIV-infected woman taking highly active antiretroviral therapy. AIDS Patient Care STDS. (2003) 17:547-50. doi: 10.1089/108729103322555935

72. Versluijs-Ossewaarde FNL, Roumen RMH, Goris RJA. Subareolar breast abscesses: characteristics and results of surgical treatment. Breast J. (2005) 11:179-82. doi: 10.1111/j.1075-122X.2005.21524.x

73. Darré T, Tchaou M, N’Timon B, Patassi AA, Aboubakari A, Sonhaye L, et al. Tuberculose mammaire au Togo: à propos de 28 cas présumés. Bull la Soc Pathol Exot. (2017) 110:238-41. doi: 10.1007/s13149-017-0576-8

74. Shinde SR, Chandawarkar RY, Deshmukh SP. Tuberculosis of the breast masquerading as carcinoma: a study of 100 patients. World J Surg. (1995) 19:379-81. doi: 10.1007/BF00299163

75. Kilic MO, Sałlam C, Atca FD, Terziollu SG. Clinical, diagnostic and therapeutic management of patients with breast tuberculosis: analysis of 46 Cases. Kaohsiung J Med Sci. (2016) 32:27-31. doi: 10.1016/j.kjms.2015. 12.005 
76. Aghajanzadeh M, Hassanzadeh R, Alizadeh Sefat S, Alavi A, Hemmati H, Esmaeili Delshad MS, et al. Granulomatous mastitis: presentations, diagnosis, treatment and outcome in 206 patients from the north of Iran. Breast. (2015) 24:456-60. doi: 10.1016/j.breast.2015.04.003

77. Bashir MU, Ramcharan A, Alothman S, Beaugris S, Khan SA, Sbeih MA, et al. The enigma of granulomatous mastitis: a series. Breast Dis. (2017) 37:17-20. doi: 10.3233/BD-160261

78. Florio MAG, Famà F, Buccheri G, Di Cara G, Pollicino A, Scarfò P, et al. Le lesioni infiammatorie non puerperali della mammella. Ann Ital Chir. (2006) 77:127-30.

79. Doede AL, Mitchell EM, Wilson D, Panagides R, Oriá MOB. Knowledge, beliefs, and attitudes about breast cancer screening in Latin America and the Caribbean: an in-depth narrative review. J Glob Oncol. (2018) 4:125. doi: 10.1200/JGO.18.00053

80. Duda RB, Bhushan D. Teaching rural women in Nicaragua the principles of breast health. J Cancer Educ. (2011) 26:5605. doi: 10.1007/s13187-011-0244-9

81. Duggan C, Dvaladze A, Scheel JR, Stevens LM, Anderson BO. Situational analysis of breast health care systems: why context matters. Cancer. (2020) 126:2405-15. doi: 10.1002/cncr.32899

82. Asoglu O, Ozmen V, Karanlik H, Tunaci M, Cabioglu N, Abdullah I, et al. Feasibility of surgical management in patients with granulomatous mastitis. Breast J. (2005) 11:108-14. doi: 10.1111/j.1075-122X.2005.21576.x

83. Lin TL, Chi SY, Liu JW, Chou FF. Tuberculosis of the breast: 10 years' experience in one institution. Int J Tuberc Lung Dis. (2010) 14:758-63.

84. Abdelhadi MSA, Bukharie HA. Breast infections in non-lactating women. $J$ Family Community Med. (2005) 12:133-7.

85. Cooper SA. Illustrations of the diseases of the breast. In: Johnson J, editor. The Medico-Chirurgical Review. Flanders. Belgium: Burgess and Hill (1829). p. 396.

86. Baharoon S. Tuberculosis of the breast. Ann Thorac Med. (2008) 3:110. doi: 10.4103/1817-1737.41918

87. Pérez P. JA, Bohle O. J, Sánchez C. G, Carrasco L. C, Mariángel P. P. Mastitis granulomatosa idiopática: diagnóstico y tratamiento en 14 casos. Rev Chil cirugía. (2007) 59:259-63. doi: 10.4067/S0718-40262007000400003
88. Yasar K, Pehlivagohlu F, Sengoz G, Cabioglu N. Successfully treated Mycobacterium abscessus mastitis: a rare cause of breast masses. Indian J Med Microbiol. (2011) 29:425-7. doi: 10.4103/0255-0857.90187

89. Cooke F, Friedland J. Spontaneous breast abscess due to Mycobacterium fortuitum. Clin Infect Dis. (1998) 26:760-1. doi: 10.1086/5 17117

90. Stone N, Gillett P, Burge S. Breast abscess due to Corynebacterium striatum. Br J Dermatol. (1997) 137:623-5. doi: 10.1111/j.1365-2133.1997.tb 03799.x

91. Riegel P, Liégeois P, Chenard MP, Mathelin C, Monteil H. Isolations of Corynebacterium kroppenstedtii from a breast abscess. Int J Med Microbiol. (2004) 294:413-6. doi: 10.1016/j.ijmm.2004.07.013

92. Kayahan M, Kadioglu H, Muslumanoglu M. Management of patients with granulomatous mastitis: analysis of 31 cases. Breast Care. (2012) 7:22630. doi: $10.1159 / 000337758$

Conflict of Interest: The authors declare that the research was conducted in the absence of any commercial or financial relationships that could be construed as a potential conflict of interest.

Publisher's Note: All claims expressed in this article are solely those of the authors and do not necessarily represent those of their affiliated organizations, or those of the publisher, the editors and the reviewers. Any product that may be evaluated in this article, or claim that may be made by its manufacturer, is not guaranteed or endorsed by the publisher.

Copyright (c) 2021 Costa Morais Oliveira, Cubas-Vega, López Del-Tejo, Baía-daSilva, Araújo Tavares, Picinin Safe, Cordeiro-Santos, Lacerda and Val. This is an open-access article distributed under the terms of the Creative Commons Attribution License (CC BY). The use, distribution or reproduction in other forums is permitted, provided the original author(s) and the copyright owner(s) are credited and that the original publication in this journal is cited, in accordance with accepted academic practice. No use, distribution or reproduction is permitted which does not comply with these terms. 